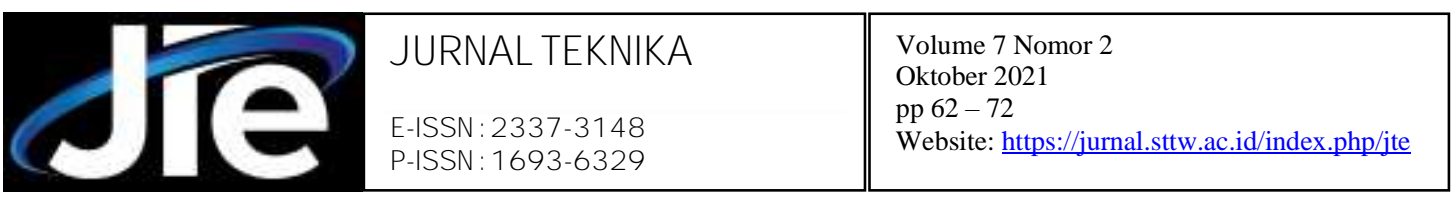

\title{
RANCANG BANGUN ALAT PERAGA PEMBELAJARAN KENDALI CERDAS DENGAN MIKROKONTROLLER AVR
}

\author{
Rahmat $^{1}$, Wiyono ${ }^{2}$ \\ 1,2 Program Studi Teknik Elektronika, Sekolah Tinggi Teknologi “Warga” Surakarta \\ Email: rahmatteatw@gmail.com
}

\begin{abstract}
ABSTRAK
Kesulitan dalam memahami konsep mata kuliah kendali hampir dialami bagi mahasiswa yang mengambil mata kuliah teknik kendali. Dengan adanya alat peraga pembelajaran dimaksudkan untuk membantu mahasiswa memahami konsep sistem kendali secara nyata dalam bentuk rangkaian kendali nyata. Tahapan pembuatan alat peraga pembelajaran dilakukan dengan pembuatan program dan rangkaian mikrokontroller untuk aplikasi kendali intensitas cahaya, kendali kecepatan motor DC dan kendali motor stepper. Dari hasil tahapan perancangan modul dan pembuatan serta uji coba modul pembelajaran mikokontroller avr pada penerapan kendali cerdas telah dilakukan percobaan perubahan sinyal DC PWM (Pulse Width Modulation) dari rangkaian mikrontroller dengan dutycycle 25-99 untuk mengendalikan tegangan untuk beban lampu pijar untuk menghasilkan intensitas cahaya 202-8120 lux, percobaan perubahan sinyal DC $P W M$ dari rangkaian mikrokontroller dengan dutycycle 50 - 100 untuk mengendalikan kecepatan motor DC dari $131-$ $240 \mathrm{rpm}$, percobaan pembakit pulse dari rangkaian mikrokontroller untuk mengatur posisi gerakan motor stepper dengan pulse yang dibangkitkan 6.25 - 50 untuk mengatur posisi dari 45 derajat sampai 360 derajat. Dari hasil percobaan pengaturan intensitas cahaya, pengaturan kecepatan motor DC dan pengaturan posisi motor stepper merupakan realisasi aplikasi nyata dalam materi pembelajaran teknik kendali cerdas yang dapat membantu mahasiswa dalam pemahaman penerapan teknik kendali cerdas dalam penerapan nyata. Modul hasil percobaan bisa digunakan sebagai sarana pembelajaran sebagai alat peraga pembelajaran pada mata kuliah teknik kendali cerdas untuk membuktikan proses pengendalian intensitas cahaya, pengaturan kecepatan motor DC dan pengaturan posisi gerakan motor stepper menggunakan rangkaian kendali mikrokontroller AVR.
\end{abstract}

Kata kunci: Peraga Pembelajaran, Kendali, Mikrokontroller

\section{ABSTRACT}

Difficulties in understanding the concept of control courses are almost experienced by students who take control engineering courses. The existence of learning aids is intended to help students understand the concept of a real control system in the form of a real control circuit. The stages of making learning aids are done by making programs and microcontroller circuits for light intensity control applications, DC motor speed control and stepper motor control. From the results of the module design and manufacture and testing of the Avr microcontroller learning module on the application of intelligent control, an experiment on changing the DC PWM (Pulse Width Modulation) signal from the microcontroller circuit with a duty cycle of 25-99 has been carried out to control the voltage for the incandescent lamp load to produce a light intensity of $202-8120$ lux, experiment on changing the DC PWM signal from a microcontroller circuit with a duty cycle of 50 - 100 to control the speed of a DC motor from 131 - 240 rpm, experiment with generating pulses from a microcontroller circuit to adjust the position of the stepper motor movement with a pulse generated $6.25-50$ to adjust the position from 45 degrees to 360 degrees. From the experimental results of light intensity regulation, DC motor speed regulation and stepper motor position adjustment, it is the realization of a real application in learning material for intelligent control techniques that can help students understand the application of intelligent control techniques in real applications. The experimental results module can be used as a learning tool as a learning aid in intelligent control engineering courses to prove the process of controlling light intensity, controlling DC motor speed and adjusting the position of stepper motor movement using the AVR microcontroller control circuit.

Keywords: Learning Model, Control, Microcontroller 


\section{PENDAHULUAN}

Tuntutan lulusan perguruan tinggi untuk dapat beradaptasi dengan cepat dengan tuntutan dunia pekerjaan terutama lulusan perguruan tinggi vokasi menjadi tantangan tersendiri bagi penyelenggara pendidikan vokasi. Penguasan materi terapan diawali dengan pemahaman konsep-konsep yang dipelajari dimata kuliah teori di kelas teori diperlukan alat bantu untuk bisa membantu pemahaman mahasiswa dari konsep yang bersifat abstrak dan teoritis kedalam bentuk nyata yang bisa diamati yang mengimplementasikan dari teoriteori yang dipelajari. Alat bantu pembelajaran digunakan, dibuat dan diciptakan untuk membantu pemahaman siswa ataupun mahasiswa atau pembelajar untuk memahami konsep kedalam bentuk terapan yang nyata. Media pembelajaran adalah wahana penyalur pesan dan informasi belajar untuk membantu peserta didik atau mahasiswa mencapai tujuan pembelajaran. Masing-masing jenis media pembelajaran memiliki karakteristik, kelebihan serta kekurangan maka perlu adanya perancangan untuk penggunaan media pembelajaran[1]. Tren dari revolusi industri 4.0 menjadikan mikrokontroller semakin banyak diminati untuk dikembangkan, bahkan setiap lembaga pendidikan mulai mengkaji secara mendalam pada bidang mikrokontroller untuk dimasukan kedalam kurikulum pendidikan[2].

Alat peraga pembelajaran adalah alat untuk memberikan pelajaran atau yang dapat diamati melalui panca indera. Alat peraga merupakan salah satu dari media pendidikan adalah untuk membantu proses belajar mengajar agar proses komunikasi dapat berhasil dengan baik dan efektif[3]. Sebuah konsekuensi dari dicantumkannya materi mikrokontroller dalam kurikulum sebuah kewajiban bagi tenaga pengajar untuk mencapai kompetensi lulusan dengan mengemas pembelajaran seoptimal mungkin, salah satunya pembuatan dan penggunaan media pembelajaran sebagai upaya untuk ketercapaian kompetensi siswa atau mahasiswa yang mempelajari mikrokontroller. Lebih spesifik lagi dalam penelitian ini pembuatan alat peraga pembejaran ini dimaksudkan untuk pencapaian kompetensi mahasiswa dalam penguasan materi perkuliahan Kendali Cerdas.

Sejak revolusi industri di beberapa negara di Eropa, teknologi dikembangkan dan tumbuh dengan cepat. Dari era revolusi industri dan era globalisasi mengubah cara berpikir yang sangat berbeda. Termasuk dengan berkembangnya teknologi robotika[4]. Mikrokontroller sebagai perangkat digital mempunyai input, output, dan kontrol program, dengan program yang bisa ditulis dan dihapus sesuai keperluan. Mikrokontroller mengatur pembacaan dan penulisan data. Sebuah komputer dalam sebuah Chip yang digunakan untuk mengontrol peralatan elektronik dengan sangat efisien dan harga yang murah yang kita kenal dengan mikrokontoller[5]. Mikrokontroller dan pengolah sinyal digital banyak diintegrasikan sebagai rangkaian PWM, untuk menghasilkan lebar pulsa sinyal termodulasi dengan menseting key word di dalam program[6].

Dengan kemampuan mikrokontroller untuk dimanfaatkan sebagai perangkat kendali untuk berbagai keperluan, lebih khusus untuk keperluan pengendalian perangkat untuk keperluan kontrol proses di industri. Motor DC saat ini banyak digunakan untuk sistem kendali, untuk fractional horse power dan sistem penggerak dengan kecepatan yang berubah-ubah salah satu pilihannya menggunakan penggerak motor DC disebabkan torsi tinggi dengan regulasi kecepatan yang rendah. Dengan berkembangnya teknologi mikrokontroller, mikrokontroller sebagai sebuah chip yang banyak digunakan untuk mengendalikan perangkat elektro mekanik[7]. Pengaturan kecepatan motor DC diperlukan untuk mengatur gerakan robot dan sistem otomasi di industri. PWM sebagai salah satu metoda untuk mengatur kecepatan motor[8].

Penelitian ini dimaksudkan untuk membuat modul/alat peraga pembelajaran untuk mempermudah dalam memberikan pemahaman konsep sistem kendali pada mata kuliah kendali cerdas yang mana diperlukan sebuah sarana pembelajaran sebagai alat bantu yang memberikan gambaran nyata dalam bentuk rangkaian kendali terapan dengan 
menggunakan mikrokontroller untuk mengendalikan intensitas cahaya, kecepatan motor DC dan pengaturan kecepatan dan posisi motor stepper.

\section{METODE PENELITIAN}

Tahapan penelitian ini diawali dengan menyiapkan peralatan dan bahan yang diperlukan dalam kegiatan penelitian, yang selanjutnya dilakukan tahapan kegiatan penelitian sebagai metode untuk mendapatkan data dari modul pembelajaran yang dibuat.

Alat dan Bahan :

- Komputer PC /Laptop

- Minimum Sistem Mikrokontroller AVR Atmega

- Motor Stepper

- Motor DC

- Lampu Bohlam

- Rpm Meter

- Lux Meter

- AVO Meter

\section{Metoda Penelitian :}

- Mengidentifikasi modul aplikasi yang diperlukan pada mata kuliah Kendali Cerdas.

- Menyiapkan modul rangkaian untuk aplikasi yang akan dibuat

- Membuat program yang akan didownload ke mikrokontroller

- Merakit/merangkai modul aplikasi yang akan dikendalikan mikrokontroller

- Melakukan uji coba rangkaian dan program untuk setiap modul aplikasi

- Mengambil data percobaan untuk setiap modul aplikasi

- Membuat kesimpulan

- Mengemas modul aplikasi dalam bentuk alat peraga pembelajaran sebagai penunjang kegiatan perkuliahan

- Menyusun laporan kegiatan penelitian

Pelaksanaan dan pengambilan data penelitian ini dilakukan di Laboratorium Program Studi Teknik Elektronika STT Warga Surakarta.

\subsection{Perancangan Program}

Untuk merealisasikan alat peraga pembelajaran yang membantu mahasiswa untuk memahami dan dapat merealisasikan dalam bentuk rangkaian nyata dilakukan dua tahapan yaitu perancangan/pembuatan program dan merakit modul mikrokontroller. Tahapan yang pertama merancang program, adapun rancangan program untuk kendali intensitas cahaya sebagai berikut :

seting timer counter 1 (PWM)

// Timer/Counter 1 initialization

// Clock source: System Clock

// Clock value: $62,500 \mathrm{kHz}$

// Mode: Fast PWM top=00FFh

// OC1A output: Inverted

// OC1B output: Non-Inv.

TCCR1A=0xE1;

TCCR1B=0x0B; 


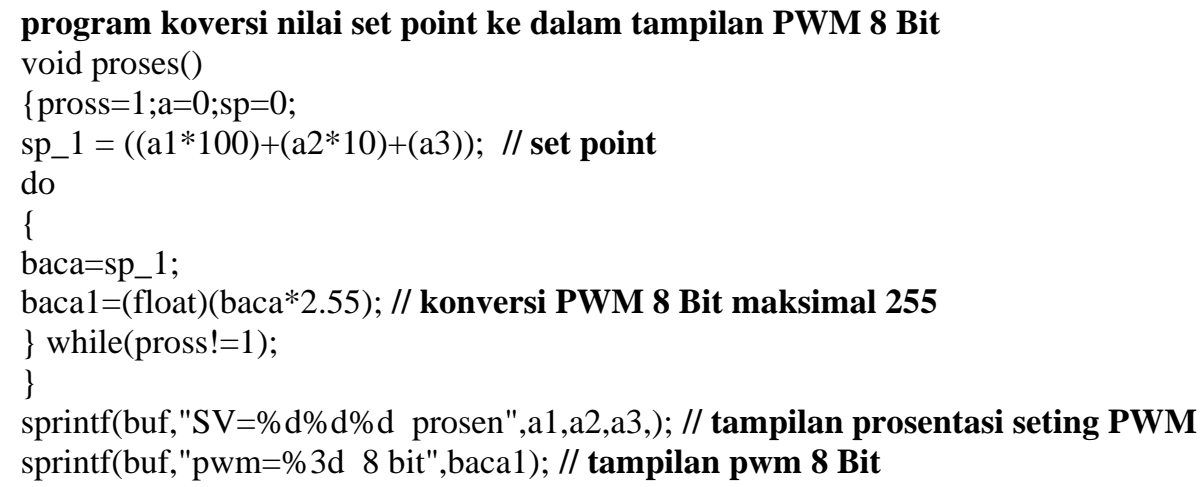

Tampilan dutycycle 50\% dan 80 seperti gambar 1 dan gambar 2.

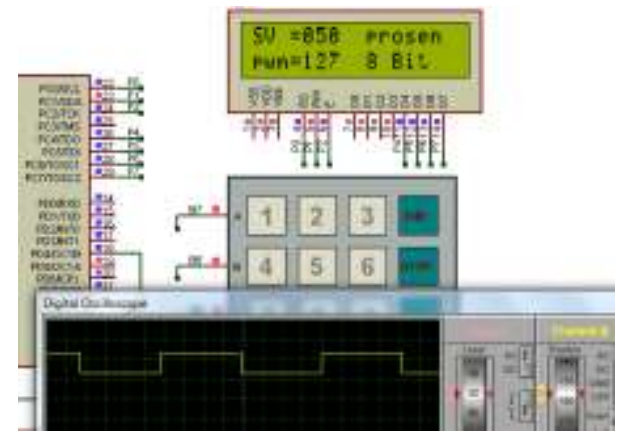

Gambar 1. Tampilan dutycycle 50\% ke angka pwm 8 bit

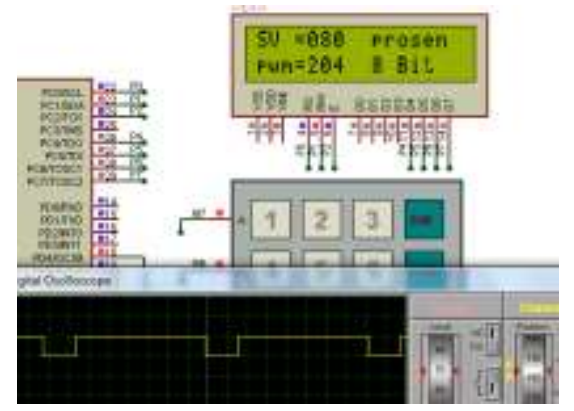

Gambar 2. Tampilan dutycycle $80 \%$ ke angka pwm 8 bit

Untuk rancangan program pengendalian motor DC sebagai berikut :

seting timer counter 2 (PWM)

// Timer/Counter 2 initialization

// Clock source: System Clock

// Clock value: $125.000 \mathrm{kHz}$

// Mode: Fast PWM top=FFh

// OC2 output: Non-Inverted PWM

$\mathrm{ASSR}=0 \mathrm{x} 00$

TCCR2 $=0 \times 6 \mathrm{~B}$;

TCNT2 $=0 \times 00$

OCR2 $=0 \times 00$;

program pembalik putaran motor $\mathrm{DC}$

void putar()

\{ 
delay_ms(70);balik= balik;delay_ms(100); $\operatorname{arah}=12 ;\}$;

program koversi nilai set point ke dalam tampilan PWM 8 Bit

//fungsi pembacaan nilai setpoint

void proses()

$\{$ pross $=1 ; \mathrm{a}=0 ; \mathrm{sp}=0$;

sp_1 $=((\mathrm{a} 1 * 100)+(\mathrm{a} 2 * 10)+(\mathrm{a} 3))$;

do

\{

baca=sp_1;

baca2 $=($ float $)($ baca*2.55);

\} while(pross!=1);

\}

program pengendali driver pembalik putaran motor DC

if (balik==0) $\{$ PORTD. $0=1 ;$ PORTD. $1=0 ;\}$;

if (balik==1) $\{$ PORTD. $0=0 ;$ PORTD. $1=1 ;\}$;

lcd_gotoxy $(0,0)$;

sprintf(buf,"SV=\%d\%d\%d Prosen ",a1,a2,a3); // tampilan kecepatan dalam prosentasi

seting PWM

lcd_gotoxy $(0,1)$;

sprintf(buf,"pwm=\%3d arah=\%d",baca2,balik); // tampilan pwm 8 Bit dan kode arah

putaran motor

lcd_puts(buf);

Tampilan dutycycle 50\% dan 90\% seperti gambar 3 dan gambar 4.

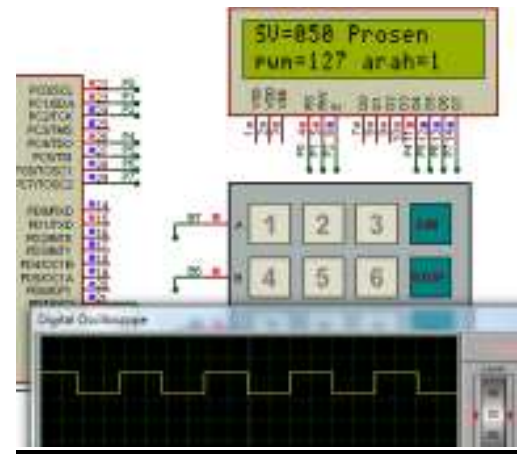

Gambar 3. Tampilan dutycycle $50 \%$ ke angka pwm 8 bit, arah=1 maju

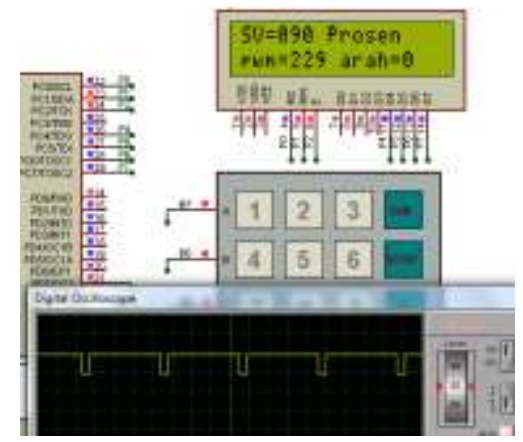

Gambar 4. Tampilan dutycycle $90 \%$ ke angka pwm 8 bit, arah=0 mundur

Adapun rancangan program pengendalian motor stepper ditunjukan pada program sebagai berikut :

program nilai set kecepatan dan sudut putaran

void proses()

$\{$ pross $=1 ; \mathrm{a}=0 ; \mathrm{sp}=0$; 


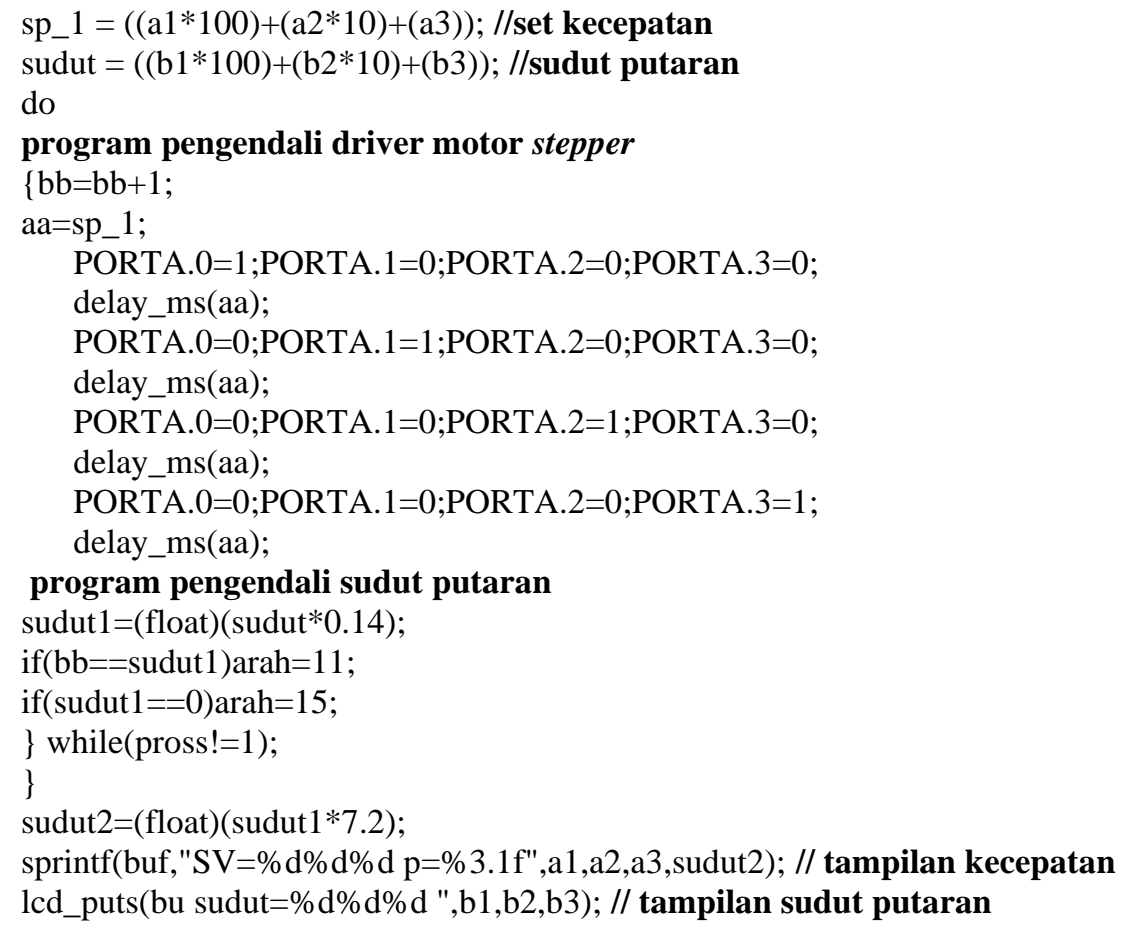

\subsection{Perakitan Modul Pembelajaran}

Perakitan modul pembelajaran meliputi modul pengendalian intensitas cahaya, modul pengendalian kecepatan motor DC dan Modul pengendalian motor stepper. Semua perangkat untuk keperluan pengendalian tersebut meliputi : Minimum sistem AVR, KeyPad, LCD display, Motor DC, Motor Stepper, Beban lampu pijar, Protoboard, Downloader dan catu daya. Semua perangkat di letakkan pada papan percobaaan modul pelatihan (Modul Trainer). Hasil perakitan modul ditunjukan pada gambar 5.

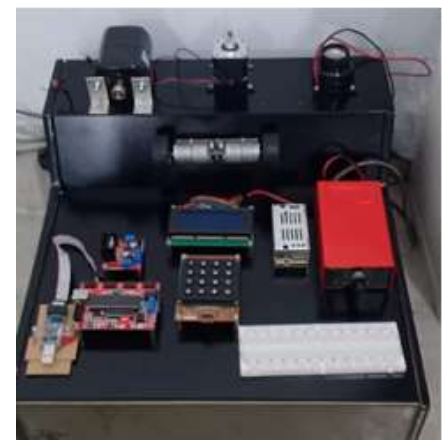

Gambar 5. Modul Peraga Pembelajaran Mikrokontroller AVR

\subsection{Pengujian}

Setelah tahapan proses persiapan komponen semua komponen dirakit dan menghasilkan modul pembelajaran, tahapan selanjutnya melakukan pengujian program pada modul pelatihan . Berikut modul aplikasi dasar yang di ujikan dalam perancagan penggunaan alat peraga pembelajaran ini 
a. Modul pengaturan intensitas cahaya.

Hasil pengujian Modul Kendali intensitas cahaya ditunjukan bagian hasil penelitian. Pengambilan data intensitas cahaya dengan menggunakan lux meter seperti ditunjukan pada gambar gambar 6 .

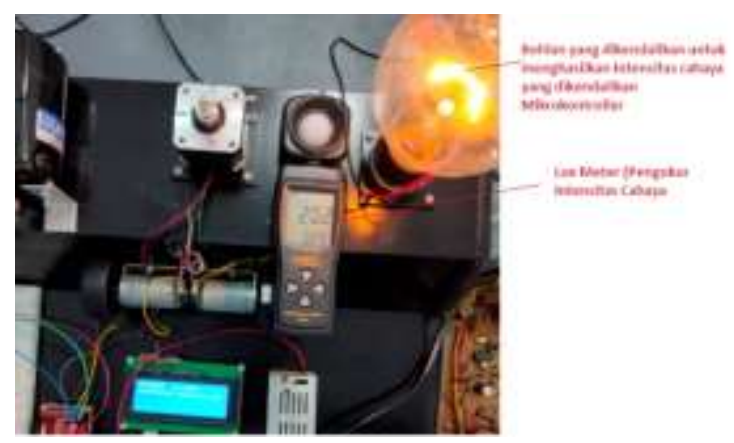

Gambar 6. Pengambilan data pada modul pengaturan intensistas cahaya

b. Modul pengaturan kecepatan motor DC

Hasil pengujian Modul Kendali kecepatan motor DC ditunjukkan pada bagian hasil penelitian. Pengambilan data kecepatan motor dilakukan dengan menggunakan Rpm Meter seperti ditunjukan pada gambar 7.

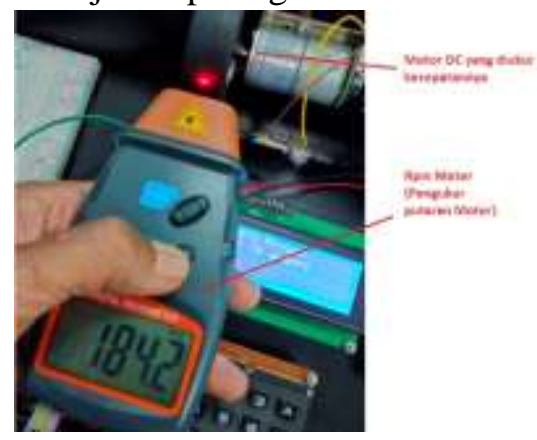

Gambar 7. Pengambilan data pada modul pengaturan kecepatan motor DC

c. Modul pengaturan kecepatan Motor Stepper

Hasil pengujian Modul Kendali Motor Stepper ditunjukan pada bagian hasil penelitian Pengambilan data posisi putaran motor dilakukan dengan pengamatan posisi motor seperti ditunjukan pada gambar 8 .
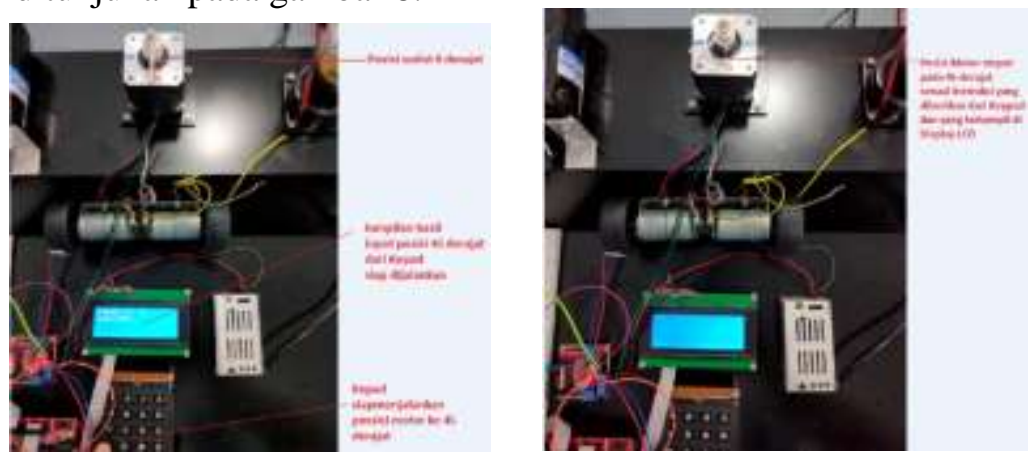

Gambar 8. Pengambilan data pada modul pengaturan kecepatan motor Stepper 


\section{HASIL DAN PEMBAHASAN}

Setelah tahapan proses persiapan komponen, semua komponen dirakit dan menghasilkan modul pembelajaran dalam bentuk trainer selanjutnya dilakukan pengambilan data percobaan.

a. Modul pengaturan intensitas cahaya.

Hasil pengujian Modul Kendali intensitas cahaya pada pengujian dutycycle luaran tegangan DC PWM yang di berikan pada rangkaian zero crossing detector terhadap Intensitas Cahaya dengan menggunakan Lampu Pijar 200W ditunjukan pada Tabel 1 .

Tabel 1. Data Kendali Intensistas Cahaya

\begin{tabular}{cc}
\hline $\begin{array}{c}\text { Prosentase Duty Cycle luaran } \\
\text { tegangan DC PWM }\end{array}$ & Intensitas Cahaya (Lux) \\
\hline 99 & 8120 \\
80 & 6120 \\
70 & 6012 \\
60 & 4121 \\
50 & 2327 \\
40 & 964 \\
30 & 308 \\
25 & 202 \\
\hline
\end{tabular}

Kurva Kendali Intensitas Cahaya

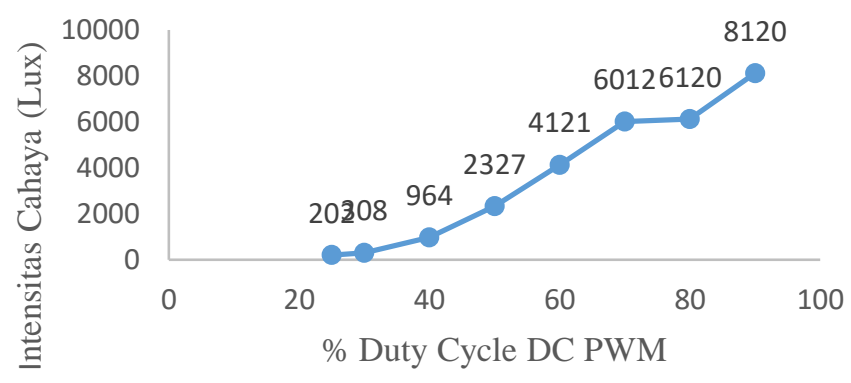

Gambar 9. Kurva Kendali Intensitas Cahaya

Dari data tabel dan kurva kendali intensitas cahaya menunjukan pengaturan Prosentase dutycycle luaran tegangan DC PWM terhadap intensitas cahaya. Semakin besar prosentase dutycycle DC PWM semakin kuat intensitas cahaya yang dihasilkan lampu.

b. Modul pengaturan kecepatan motor DC

Driver motor berfungsi sebagai penguat dari mikrokontroller mengeluarkan dan mengontrol motor sehingga dapat maju dan mundur [4]. Beberapa peneliti telah meneliti penerapan PWM dengan mikrokontroller, seperti kendali tegangan motor induksi satu fasa menggunakan PWM asimetris logika Fuzzy [5]. Hasil pengujian Modul Kendali kecepatan motor pada dutycycle luaran tegangan DC PWM yang di berikan pada rangkaian driver motor terhadap kecepatan motor DC ditunjukan pada Tabel 2. 
Tabel 2. Kendali KecepatanMotor DC

\begin{tabular}{cc}
\hline $\begin{array}{c}\text { Prosentase dutycycle luaran } \\
\text { tegangan DC PWM (dalam \%) }\end{array}$ & Kecepatan Motor DC (RPM) \\
\hline 100 & 240 \\
90 & 210 \\
80 & 198 \\
70 & 184 \\
60 & 151 \\
50 & 131 \\
\hline
\end{tabular}

\section{Kurva Kendali Kecepatan Motor DC}

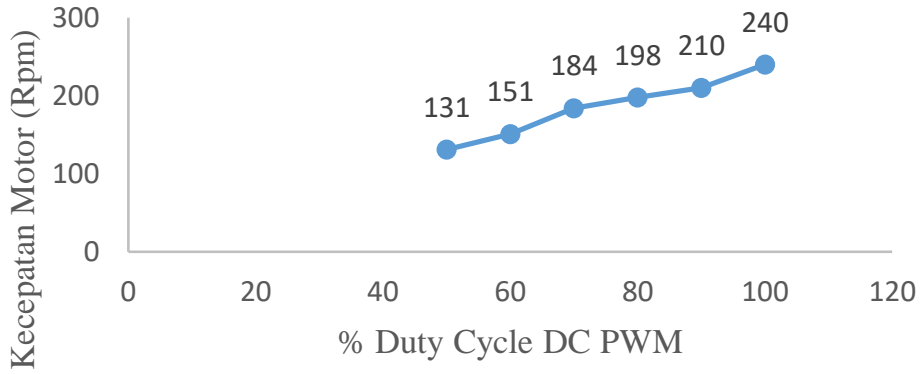

Gambar 10. Kurva Kendali Kecepatan Motor DC

Dari data tabel dan kurva kendali kecepatan motor DC menunjukan pengaturan Prosentase dutycycle luaran tegangan DC PWM terhadap kecepatan motor DC. Semakin besar prosentase dutycycle DC $P W M$ semakin cepat putaran motor DC.

c. Modul pengaturan kecepatan motor stepper

Ada beberapa jenis DC driver motor yang biasa kita gunakan, seperti menggunakan relay yang diaktifkan oleh transistor sebagai saklar, tetapi itu dianggap tidak efisien dalam mengerjakan perangkat keras [4]. Hasil pengujian Modul Kendali Motor untuk pengaturan Siklus sinyal kendali terhadap sudut posisi motor stepper ditunjukkan pada Tabel 3 .

Tabel 3. data hasil percobaan untuk kendali posisi motor stepper

\begin{tabular}{cc}
\hline $\begin{array}{c}\text { Siklus geseran sinyal data } \\
\text { driver motor stepper }\end{array}$ & Posisi sudut motor Stepper \\
\hline 50 & 360 \\
25 & 180 \\
12,5 & 90 \\
6,25 & 45 \\
\hline
\end{tabular}




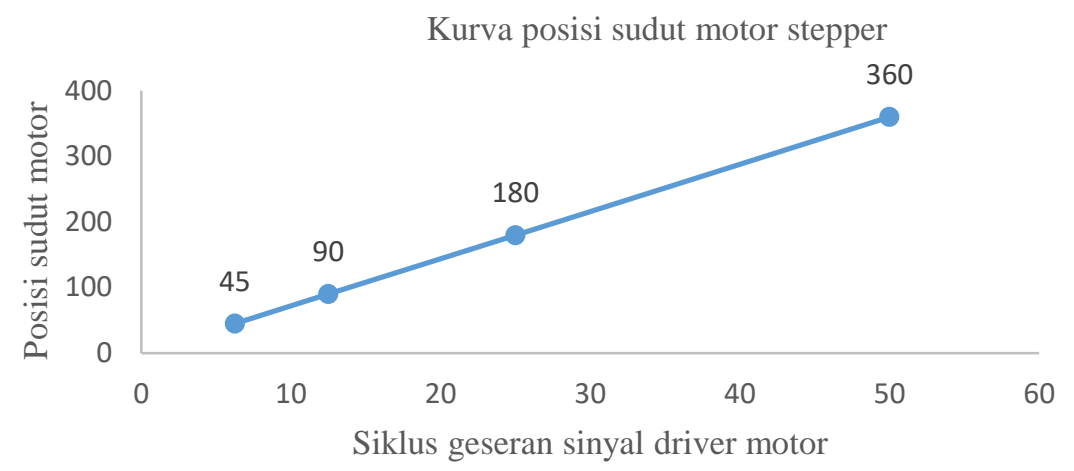

Gambar 11. Kurva posisi sudut motor stepper

Dari data tabel dan kurva posisi sudut motor stepper menunjukan pengaturan siklus geseran sinyal data driver motor stepper terhadap posisi sudut motor stepper, bahwa posisi putaran motor stepper ditentukan oleh siklus geseran sinyal data driver motor stepper.

\section{KESIMPULAN}

Dari hasil tahapan perencangan modul dan pembuatan serta uji coba modul pembelajaran mikrokontroler avr pada penerapan kendali cerdas telah berhasil dibuat alat peraga pembelajaran sebagai alat bantu dalam proses pembelajaran aplikasi mikrokontroler AVR pada mata Kuliah Kendali Cerdas. Hasil percobaan pada modul:

a. Kendali Intensitas cahaya

Percobaan perubahan sinyal DC PWM dari rangkaian mikrokontroller dengan dutycycle 25-99\% untuk mengendalikan tegangan untuk beban lampu pijar untuk menghasilkan intensitas cahaya 202-8120 lux

b. Kendali keceparan motor DC

Percobaan perubahan sinyal DC PWM dari rangkaian mikrokontroller dengan dutycycle $50-100 \%$ untuk mengendalikan kecepatan motor DC dari 131 $240 \mathrm{rpm}$

c. Kendali motor stepper

Percobaan pembangkit pulse dari rangkaian mikrokontroller untuk mengatur posisi gerakan motor stepper dengan pulse yang dibangkitkan $6.25-50$ pulse untuk mengatur posisi dari 45 derajat sampai 360 derajat

\section{DAFTAR PUSTAKA}

[1] N. Supriyana, E. Permata, and M. Fatkhurrokhman, "Pengembangan Media Pembelajaran Trainer Mikrokontroller Atmega 16 Di Program Studi Pendidikan Vokasional Teknik Elektro," Jurnal Taman Vokasi, vol. 7, pp. 150-158, 2019.

[2] D. Nahrowi, D. Aribowo, and M. Abi Hamid, "Pengembangan Trainer Kit Mikrokontroler ATMega16 Sebagai Media Pembelajaran Untuk Sekolah Menengah Kejuruan," Jurnal Pendidikan Teknologi dan Kejuruan, vol. 17, pp. 145-155, 2020.

[3] S. J. Sokop, D. J. Mamahit, and S. R. Sompie, "Trainer periferal antarmuka berbasis mikrokontroler arduino uno," Jurnal Teknik Elektro Dan Komputer, vol. 5, pp. 13-23, 2016. 
[4] A. Latif, H. A. Widodo, R. Rahim, and K. Kunal, "Implementation of Line Follower Robot based Microcontroller ATMega32A," Journal of Robotics and Control (JRC), vol. 1, pp. 70-74, 2020.

[5] D. Setiawan, I. Ishak, and M. A. Sembiring, "Control System for Adjusting the Brightness Level with PWM Technique Using Visual Net Microcontroller-Based," Journal of Robotics and Control (JRC), vol. 1, pp. 102-108, 2020.

[6] Z. Xu and Y. Kang, "PWM speed DC motor drive power design," in 2016 31st Youth Academic Annual Conference of Chinese Association of Automation (YAC), 2016, pp. 419-423.

[7] M. K. Russel and M. H. Bhuyan, "Microcontroller Based DC Motor Speed Control Using PWM Technique," in Proceedings of the International Conference on Electrical, Computer and Telecommunications Engineering RUET, Rajshahi, Bangladesh, 2012, pp. 1-2.

[8] K. M. Raza, K. Mohd, and P. Kumar, "Speed Control of DC Motor by using PWM," International Journal of Advanced Research in Computer and Communication Engineering, vol. 5, 2016. 